\title{
SECONDARY HYPERTENSION: DIFFERENTIAL DIAGNOSIS AND BASIC PRINCIPLES OF TREATMENT
}

Sasa Jacovic ${ }^{1}$, Marija Zivkovic-Radojevic ${ }^{2}$, Dejan Petrovic ${ }^{2,3}$

${ }^{1}$ Medicines and Medical Devices Agency of Serbia, Belgrade, Serbia

${ }^{2}$ Faculty of Medical Sciences, University of Kragujevac, Kragujevac, Serbia

${ }^{3}$ Center of Nephrology and Dialysis, Department of Urology and Nephrology, Clinical Center Kragujevac, Kragujevac, Serbia

\author{
SEIKUNDARNA HIPERTENZIJA: \\ DIFERENCIJALNA DIJAGNOZA I OSNOVNI PRINCIPI LEČENJA \\ Saša Jaćović ${ }^{1}$, Marija Živković-Radojević2 , Dejan Petrovićé, \\ ${ }^{1}$ Agencija za lekove i medicinska sredstva Republike Srbije, Beograd \\ ${ }^{2}$ Fakultet medicinskih nauka, Univerzitet u Kragujevcu, Kragujevac, Srbija \\ ${ }^{3}$ Centar za nefrologiju i dijalizu, Klinika za urologiju i nefrologiju, KC Kragujevac
}

\section{ABSTRACT}

Secondary hypertension occurs in 5-10\% of cases in the patient population with primary hypertension. The most common forms of secondary hypertension are as follows: parenchymal renal disease (renoparenchymal hypertension), renal artery stenosis (renovascular hypertension), adrenal gland adenoma (primary hyperaldosteronism), a tumour of the adrenal gland marrow (pheochromocytoma) and adenoma of adrenal and pituitary glands (Cushing's syndrome). In patients with a typical clinical picture of secondary hypertension, the appropriate diagnostic tests should be conducted based on the suspected form of secondary hypertension. Determining a diagnosis of secondary hypertension is gradual. First, the appropriate screening tests are performed. If the screening test is positive, then additional tests to confirm the forms of secondary hypertension are conducted. Once a diagnosis of the appropriate form of secondary hypertension is confirmed, tests to distinguish causes and laterality tests to determine the precise localisation of the pathological process are applied to evaluate the response to therapy. Analysing the results of endocrine diagnostic tests provides an accurate diagnosis and selection of optimal therapeutic procedures.

Keywords: secondary hypertension, renoparenchymal hypertension, renovascular hypertension, primary aldosteronism, pheochromocytoma, Cushing's syndrome

\section{SAŽETAK}

Sekundarna hipertenzija se javlja kod 5-10\% slučajeva u populaciji bolesnika sa hipertenzijom. Najčešći uzroci sekundarne hipertenzije su: parenhimska bolest bubrega (renoparenhimska hipertenzija), stenoza renalne arterije (renovaskularna hipertenzija), adenom nadbubrežne žlezde (primarni hiperaldosteronizam), tumour srži nadbubrežne žlezde (feohromocitom) $i$ adenom nadbubrežne žlezde $i$ hipofize (Kušingov sindrom). Kod bolesnika sa tipičnom kliničkom slikom pojedinih oblika sekundarne hipertenzije, primenjuju se odgovarajući dijagnostički testovi. Dijagnostikovanje sekundarne hipertenzije je stepenasto. Prvo se primenjuju odgovarajući skrining testovi. Ukoliko je skrining test pozitivan, primenjuju se testovi za potvrdivanje pojedinih oblika sekundarne hipertenzije. Kada se potvrdi dijagnoza odgovarajućeg oblika sekundarne hipertenzije, primenjuju se testovi za razlikovanje uzroka, kao $i$ testovi lateralizacije, za preciznu lokalizaciju patološkog procesa i procenu odgovora na terapiju. Analiziranje rezultata više endokrinoloških dijagnostičkih testova obezbeđuje ispravnu dijagnozu i izbor optimalnog terapijskog postupka.

Ključne reči: sekundarna hipertenzija, renoparenhimska hipertenzija, renovaskularna hipertenzija, primarni aldosteronizam, feohromocitom, Cushing-ov sindrom

\section{INTRODUCTION}

Secondary hypertension is defined as hypertension that occurs due to detectable factors. In the population of patients who are suffering from hypertension (blood pressure $>140 / 90$ $\mathrm{mmHg}$ ), the prevalence of secondary hypertension is $5-10 \%$. However, in the population of patients with resistant hypertension (the impossibility of realizing a target arterial blood pressure plus the optimum dose of three antihypertensive medicines, including a diuretic), the prevalence of secondary hypertension is up to $85 \%(1,2)$. The most common forms of secondary hypertension are renoparenchymal hypertension, renovascular hypertension, hypertension due to primary aldosteronism, pheochromocytoma and Cushing's syndrome $(1,2)$. 


\section{Differential Diagnosis and}

Treatment of Secondary Hypertension

Most common causes of secondary hypertension are renal parenchymal disease, renal artery stenosis, adrenal gland adenoma (primary aldosteronism), tumor of the adrenal gland marrow (pheochromocytoma) and adenoma of the adrenal and pituitary glands (Cushing's syndrome) $(1,2)$.

\section{Renoparenchymal Hypertension}

Renoparenchymal hypertension is defined as hypertension occurring in chronic kidney disease. The prevalence of renoparenchymal hypertension in patients with hypertension is 1.6 to $8 \%$, and in the population of patients with resistant hypertension, it is $2-10 \%(3,4)$. The pathogenesis of renoparenchymal hypertension is complex and multifactorial $(3,4)$. The two most important pathogenetic mechanisms are an increased volume of extracellular fluid (the dependence of volume) and/or an increased activation of the renin-angiotensin system (dependence of angiotensin 2) $(3,4)$. Other factors that influence the development of renoparenchymal hypertension include the following: increased activity of the sympathetic nervous system, endothelial dysfunction, increased production of endothelin-1, increased oxidative stress, reduced concentration of endothelium-relaxing substances (nitric oxide - NO), changes in the arterial wall structure and sleep apnea $(3,4)$. Clinical and experimental research in recent years indicates the growing importance of increased activity of the sympathetic nervous system and obstructive sleep apnea in the development of renoparenchymal hypertension $(3,4)$. Increased activity of the sympathetic nervous system in chronic kidney disease is due to the following: activation of chemoreceptors in the kidney (renal ischaemia), decreased baroreceptor sensitivity in the kidney, decreased central dopaminergic tone, and decreased renalase activity in the kidney; additionally, renalase is flavin adenine dinucleotide-dependent amine oxidase, which degrades the catecholamines. In chronic renal disease, its activity has been reduced, and this results in the enhanced activity of the sympathetic nervous system $(3,4)$.

The measurement of serum creatinine and urine analysis (erythrocytes, cylinders and proteins) is used as the screening test for parenchymal kidney disease. If the result is positive, the endogenous creatinine clearance, 24-hour proteinuria, microalbuminuria and renal ultrasound (kidney size, the volume of renal parenchymal echogenicity and thickness, the ratio of parenchyma and the pelvis, and the atrophy index) should be determined. The atrophy index (AI) represents the ratio of the longitudinal sinus diameter and the longitudinal kidney diameter. A normal value of the atrophy index is $\mathrm{AI} \leq 0.7$ (5). An $\mathrm{AI}>0.70$ and a resistance index (RI) $>0.70$, as measured from the blood flow curve through intrarenal segmental arteries or interlobar arteries, point to tubulointerstitial chronic kidney disease (tubulointerstitial injury) (5).
The treatment consists of the application of the reninangiotensin system blockers, beta-blockers and diuretics. Thiazide diuretics are used, and loop diuretics will be applied in patients with creatinine clearance less than $30 \mathrm{ml} /$ min (a contraindication to the use of potassium-sparing diuretics) $(3,4)$.

Obstructive sleep apnea (OSA) is defined as a breathing disorder, which is characterized by recurrent obstructive apneas and hypopnea, caused by the collapse of the upper airway during sleep (sleep apnea). It often occurs in patients with chronic kidney disease (in $21-47 \%$ of patients with end stage renal disease), and the main pathogenetic mechanism for the development of hypertension is the increased activity of the sympathetic nervous system $(3,4)$. Obstructive sleep apnea causes a disorder of the circadian rhythm of blood pressure. Blood pressure is not reduced during the night in $>10 \%$ ("non-dippers"), and in patients suffering from chronic kidney disease, the prevalence of the "non-dippers" status is $74-82 \%(3,4)$. Typical clinical characteristics include obesity, large neck (neck circumference in men greater than $42 \mathrm{~cm}$ and in women greater than $39 \mathrm{~cm}$ ), macroglossia and daytime sleepiness. A history of daytime sleepiness should always arouse suspicion of obstructive sleep apnea. In these patients, an interruption of breathing during sleep is determined by using the Epworth Sleepiness Scale (ESS). Patients with an ESS score of $\geq 10$ are at high risk of obstructive sleep apnea. In these cases, polysomnography should be conducted, and based on the apnea-hypopnea index (AHI; number of apneas and hypopnea in one hour of sleep), OSA severity can be assessed. Obstructive sleep apnea (OSA) is mild if the AHI index is from $5-15 / \mathrm{h}$, moderate if AHI $=16-30 / \mathrm{h}$ and severe if AHI > 30/h (1, 3, 4). Patients who are diagnosed with OSA require echocardiography to assess the morphology and function of the left and right chambers and an estimation of the pulmonary artery pressure (pulmonary hypertension) $(1,3,4)$.

\section{Renovascular Hypertension}

Renovascular hypertension is defined as hypertension that is caused by renal artery stenosis. In the patient population with hypertension, the prevalence of renovascular hypertension amounts to $1-8 \%$, and in the patient population with resistant hypertension, its prevalence is 2.5 to $20 \%(6-8)$. The two main causes of renal artery stenosis (RAS) are atherosclerosis (90\%) and fibromuscular dysplasia $10 \%(9,10)$. Atherosclerosis affects the starting point and proximal part of the main trunk of the renal artery, which results in the development of renovascular hypertension, ischaemic nephropathy and repetitive "flash" pulmonary edema (bilateral atherosclerotic renal artery disease) $(9,10)$. Fibromuscular dysplasia (FMD) is a nonaterosklerotic, noninflammatory disease of the arteries, most commonly affecting the renal (distal part of the main trunk) and internal carotid artery $(11,12)$. Fibromuscular dysplasia of the media (70-95\% of cases) is distinguished 
by its characteristic constrictions and extensions ("string of beads") in the angiography findings $(11,12)$. In most patients, the disease is asymptomatic in the course of several years, which makes its early detection hard, and it may clinically present itself with renovascular hypertension and ischaemic nephropathy (severity of the clinical picture depends on the degree of stenosis and type of fibromuscular dysplasia) (11, 12).

Renovascular hypertension should be suspected in patients with the following: severe hypertension (diastolic blood pressure $\geq 120 \mathrm{mmHg}$ ), resistant hypertension (optimal control inability, using three antihypertensive medicines, including a diuretic), finding a hum in the auscultation of the abdomen (renal artery), moderate (diastolic blood pressure $\geq 105 \mathrm{mmHg}$ ) or severe hypertension (diastolic blood pressure $\geq 120 \mathrm{mmHg}$ ) and a difference in the size of the kidneys (the difference between the longitudinal diameter of the right and left kidney $>1.5-2.0 \mathrm{~cm}$ ), hypertension and an increase in serum creatinine concentration after the administration of angiotensin-converting-enzyme blockers 1 (ACE) and or angiotensin 2 receptor blockers (ARB) (increase of creatinine serum concentrations of 0.5$1.0 \mathrm{mg} / \mathrm{dl}(44.2-88.4 \mu \mathrm{mol} / \mathrm{l})$ after administration of ACE/ ARB) $(13,14)$.

The following screening tests are performed in these patients for the diagnosis of renovascular hypertension: plasma-renin activity (PRA), Captopril test and Color Doppler ultrasonography of the renal artery (CDU) (13, 14). Low levels of plasma renin activity (PRA $\leq 0.65 \mathrm{ng} /$ $\mathrm{ml} / \mathrm{h})$ with hypokalemia $\left(\mathrm{K}^{+}<3.5 \mathrm{mmol} / \mathrm{l}\right)$ indicate the primary aldosteronism. Moderate levels of plasma renin $(\mathrm{PRA}=0.65$ to $3.2 \mathrm{ng} / \mathrm{ml} / \mathrm{h})$ require a conduction of tests for the confirmation of renovascular hypertension (CT angiography, MR angiography). Plasma-renin activity (PRA) $\geq 3.2 \mathrm{ng} / \mathrm{ml} / \mathrm{h}$ indicates a high probability of the existence of renovascular hypertension and requires direct renovasography $(13,14)$.

The most sensitive test for the detection of renovascular hypertension is the Captopril test. Two to three weeks prior to testing, medicines affecting the PRA should be discontinued (angiotensin-converting-enzyme blockers 1, angiotensin 2 receptor blockers, beta blockers, direct renin blocker). Alpha 1-blockers (doxazosin) have no influence on the rennin concentration in plasma and plasma-renin activity. The patient needs to rest at least 30 minutes before sampling. A blood sample for the determination of the plasma-renin activity is taken 30 minutes before and 60 minutes after the administration of Captopril tablets at a dose of $25-50 \mathrm{mg}$. The test is positive if the stimulated plasma-renin activity is $\geq 12 \mathrm{ng} / \mathrm{ml} / \mathrm{h}$ or if the absolute increase of plasma-renin activity is $\geq 10$ $\mathrm{ng} / \mathrm{ml} / \mathrm{h}(13,14)$. A Color Doppler ultrasonography of the renal arteries is performed in all patients with moderate or high probability for renovascular hypertension, in which the plasma-renin activity is $\geq 1.6 \mathrm{ng} / \mathrm{ml} / \mathrm{h}$ (1517). The Direct Doppler criteria for renovascular hypertension includes the following: peak systolic blood flow velocity $(\operatorname{VmaxS})>180 \mathrm{~cm} / \mathrm{s}$, end-diastolic flow velocity (VendD) $>50 \mathrm{~cm} / \mathrm{s}$, reno-aortic index $(\mathrm{RAR})>3.5$ and reno-renal index $(R R R)>4.0$ (14-16). The indirect Doppler criteria for renovascular hypertension include: loss of early systolic peak (ESP), resistance index $(\mathrm{RI})<0.45$, acceleration time $(\mathrm{AT})>70 \mathrm{~ms}$, acceleration $(\mathrm{Acc})<300$ $\mathrm{cm} / \mathrm{s}^{2}$, the difference in resistance index $(\Delta \mathrm{RI})>0.05(>$ $5 \%$ ), the peak systolic velocity measured from the blood flow curve through interlobar arteries $<15 \mathrm{~cm} / \mathrm{s}$ and the ratio of peak systolic velocity measured from the blood flow through the interlobar arteries of both kidneys (RIR) $>5$ (renal interlobar ratio - RIR) (15-18).

If one of the screening tests for renovascular hypertension is positive, tests to confirm renovascular hypertension (computed tomographic angiography (CTA) or magnetic resonance angiography (MRA) or conventional digital subtraction angiography (DSA)) will be performed (14). These diagnostic methods require the use of a contrast agent (CTA, DSA) and gadolinium (MRA), and they are not indicated in patients with a glomerular filtration rate of less than $30 \mathrm{ml} / \mathrm{min} / 1.73 \mathrm{~m}^{2}$ due to the risk of contrast nephropathy $(\mathrm{CN})$ and nephrogenic systemic fibrosis (NSF) $(19,20)$. Digital subtraction angiography is the gold standard for the diagnosis of renovascular hypertension. It offers the possibility of the direct assessment of haemodynamic significance of renal artery stenosis [peak systolic translesion pressure gradient $(\Delta \mathrm{P}) \geq 20 \mathrm{mmHg}$, the ratio of pressure in the distal renal artery $(\mathrm{Pd})$ and the aorta $(\mathrm{Pa})$ is less than $0.9(\mathrm{Pd} / \mathrm{Pa}<0.9)](21)$.

When patients are diagnosed with renovascular hypertension, lateralization tests are applied for assessing the response after renal artery revascularization. The higher the degree of lateralization, the greater the likelihood of optimal blood pressure control and prevention of the progression of ischaemic nephropathy after renal artery revascularization $(13,14)$. The lateralization tests include a ratio of plasma-renin activity in both renal veins, Captopril scintigraphy and resistance index measured from the flow curve through intrarenal arterial segments $(\mathrm{CDU})(13,14)$. A ratio of plasma-renin activity from the renal vein stenosis of the renal artery and renal vein without renal artery stenosis greater than 1.5 indicates a good response after revascularization (lateralization of plasma-renin activity indicates haemodynamically significant stenosis) $(13,14)$. Captopril scintigraphy is used for the diagnosis of renovascular hypertension and for assessing the functionality of stenosis (positive lateralization). Firstly, dynamic renal scintigraphy without Captoprilis is performed in patients ( ${ }^{99 \mathrm{~m}}$ Tc-DTPA - diethylene triamine pentaacetic acid), and the next day, renal scintigraphy is performed after taking Captopril, per os, at a dose of $25-50 \mathrm{mg}$. The finding is positive if the decline in glomerular filtration rate (GFR) of the affected kidney $\left.{ }^{99 \mathrm{~m}} \mathrm{Tc}-\mathrm{DTPA}\right)$ is $>10 \%(13,14)$. Positive Captopril scintigraphy (positive lateralization test) indicates a positive response after revascularization (optimal control of blood pressure, prevention of loss of kidney function) $(13,14)$. 
In patients with stenosis of one renal artery, angiotensin-converting-enzyme blockers 1 and or angiotensin 2 receptor blockers are applied, with appropriate monitoring (serum creatinine concentration) (22). The application of these medicines is contraindicated if there is a stenosis of both renal arteries, due to the high risk of developing acute kidney damage (23-26). The indications for renal artery revascularization (angioplasty with or without stenting, surgical by-pass) include: renal artery stenosis $\geq 50 \%$ (systolic pressure gradient $\Delta \mathrm{P} \geq 20 \mathrm{mmHg}$ and the ratio of $\mathrm{Pd} / \mathrm{Pa}<0.9$ indicate haemodynamically significant stenosis $>60 \%$ ), resistant hypertension, loss of renal function after administration of angiotensin-converting-enzyme blockers 1 (ACEI) and or angiotensin 2 receptor blockers (ARB) (reduction of GFR $\geq 30 \%$ compared with the value before applying ACEI/ARB, an increase in serum creatinine concentration of $0.5-1.0 \mathrm{mg} / \mathrm{dl}(44.2$ to $88.4 \mu \mathrm{mol} / \mathrm{l})$ after administration of ACEI/ARB), and recurrent "flash pulmonary oedema" associated with bilateral renal artery stenosis (23-26). The contraindications for renal artery revascularization include the following: longitudinal diameter of the affected kidney less than $8.0 \mathrm{~cm}$, resistance index measured from the blood flow curve through the segmental arteries (RI) $>0.8$, chronic kidney disease (GFR $<30 \mathrm{ml}$ / $\min / 1.73 \mathrm{~m}^{2}$ ) and negative Captopril scintigraphy (absence of lateralization) (23-26).

\section{Primary Hyperaldosteronism}

Primary aldosteronism is the most common form of secondary hypertension. The main causes of the development of primary aldosteronism are adrenal gland adenoma, which secretes aldosterone, and idiopathic bilateral adrenal gland hyperplasia (27-29). The prevalence of primary aldosteronism in the patient population with hypertension is $3.5 \%$ (27-29). Screening for primary aldosteronism should be performed in patients with: resistant hypertension, moderate or severe hypertension, hypertension and hypokalemia, hypertension that is complicated by cerebrovascular events in patients younger than 40 years and patients with hypertension and swellings (27-29).

The determining of the plasma aldosterone concentration (PAC: $\mathrm{ng} / \mathrm{dl}$ ) and plasma renin activity (PRA: ng/ml/h) and the measurement of the plasma aldosterone concentration (PAC) will be conducted as the screening test for the diagnosis of primary aldosteronism (27-29). The conduction of the test requires the adequate preparation of patients: two weeks before the test patients must discontinue antihypertensive medicines that affect the renin and aldosterone concentrations in plasma (angiotensin-convertingenzyme blockers 1, angiotensin 2 receptor blockers, beta blockers, direct renin blockers), and spironolactone should be discontinued for at least two months before blood sampling for screening tests (27-29). Alpha-1-blockers (doxazosin), hydralazine, and calcium channel blockers (verapamil) have the least impact on the concentration of renin and aldosterone in the plasma (27-29). If the ratio of PAC/
PRA is $>20$ and plasma aldosterone concentration is $>15$ $\mathrm{ng} / \mathrm{dL}$ (> $416 \mathrm{pmol} / \mathrm{l}$ ), the test is positive (27-29).

Tests to confirm (confirmatory testing) primary aldosteronism should be performed in patients with positive screening tests, such as the per os sodium suppression test, IV infusion sodium suppression test and Captopril suppression test (27-29). The first test involves the per os use of $\mathrm{NaCl}$ (in addition to the normal intake of sodium of 9.0 $\mathrm{g} \mathrm{NaCl} / 24$-hours, an additional 3 x $2.0 \mathrm{~g}$ of NaCl/24-hours are applied, over the course of three days) and measurement of the aldosterone and sodium concentration in the urine on the fourth day. The test is positive if the aldosterone concentration (aldosterone-18-glucoronide) in the urine is $>12 \mu \mathrm{g} / 24 \mathrm{~h}(>33.3 \mathrm{nmol} / 24 \mathrm{~h})$ with the sodium concentration in urine being $>200 \mathrm{mmol} / 24 \mathrm{~h}$. If tetrahydroaldosterone is determined, the test is positive if the concentration in urine is $>70 \mu \mathrm{g} / 24 \mathrm{~h}$ (27-29). In the IV infusion sodium suppression test, the plasma aldosterone concentration is determined before and after the IV infusion of $2,000 \mathrm{ml}$ of $0.9 \% \mathrm{NaCl}$ solution. An IV infusion is administered in the period from 8-12 am (contraindications for IV infusion: heart weakness, history of myocardial infarction, severe and poorly controlled hypertension), the blood sample is taken at 8 am and $12 \mathrm{am}$, and the blood sample testing will determine the concentration of aldosterone, renin and cortisol in the plasma. In patients with no autonomous secretion of aldosterone, the infusion of $0.9 \% \mathrm{NaCl}$ solution blocks the secretion of aldosterone. Normal suppression is defined as the plasma concentration of aldosterone $<10 \mathrm{ng} / \mathrm{dl}(<277 \mathrm{pmol} / \mathrm{l})$. If the plasma aldosterone concentration, after IV infusion of $0.9 \% \mathrm{NaCl}$ solution over the course of $4 \mathrm{~h}$, is greater than $10 \mathrm{ng} / \mathrm{dL}$ (> $277 \mathrm{pmol} / \mathrm{l}$ ), the test is positive (confirms the diagnosis of primary aldosteronism) (27-29). In the Captopril suppression test (CST), the aldosterone concentration in serum is measured prior to and two hours after the administration of Captopril in a dose of $25 \mathrm{mg}$. The test is positive if the aldosterone concentration in the serum is (PAC) $>15 \mathrm{ng} /$ $\mathrm{dl}(>416 \mathrm{pmol} / \mathrm{l})(27-29)$.

If the screening test and confirmatory testing for primary aldosteronism are positive, tests for differential diagnosis of primary aldosteronism are applied: a display of adrenal glands (adrenal computed tomography (CT) or nuclear magnetic resonance (NMR)), as well as tests for the assessment of lateralization (concentration of aldosterone in the blood sample from the adrenal vein). Adrenal vein catheterization is conducted in centres that perform at least 10 catheterizations within one year. A sample of blood from the right and left adrenal vein and vena cava inferior is taken. In all the blood samples, the concentration of aldosterone and cortisol is determined. The selectivity index (SI) is the ratio of the concentration of cortisol in the blood sample from the adrenal vein $(\mathrm{Ca})$ and a blood sample from the vena cava inferior (Cvci) ( $\mathrm{Ca} / \mathrm{Cvci}$ ). A selectivity index $\geq 2$ represents a good position of the catheter (catheterization of adrenal veins) (27-29). The lateralization index represents the ratio of aldosterone and 
cortisol in both adrenal veins $((\mathrm{A} / \mathrm{Cd}) / \mathrm{A} / \mathrm{Cl}))$. A lateralization index $\geq 4.0$ indicates the existence of a unilateral adrenal gland adenoma, which increased the secretion of aldosterone. In idiopathic hyperaldosteronism (bilateral hyperplasia), the aldosterone/cortisol ratio from the adrenal veins is not higher than the ratio of aldosterone/cortisol from the vena cava inferior sample (27-29).

In patients with adrenal gland adenoma (positive lateralization test), the unilateral laparoscopic adrenalectomy is performed, and in patients with idiopathic bilateral hyperplasia, medicine therapy is administered (mineral corticoid receptor antagonists: spironolactone and eplerenone) (27-29). Before operative treatment, spironolactone is administered in a dose of 50-100 mg/day for four weeks, and postoperatively, fludrocortisone is often applied in a dose of $50-100 \mu \mathrm{g} /$ day (28). Spironolactone is administered for the treatment of bilateral adrenal hyperplasia, at a dose of $12.5-25 \mathrm{mg} /$ day, and the dose is gradually increased up to a dose of $100 \mathrm{mg} /$ day. A dose of spironolactone greater than $100 \mathrm{mg} /$ day is associated with side effects, such as: gynaecomastia, loss of libido, erectile dysfunction in men and disorder of cyclic menses in a woman. Regular monitoring of patients includes an assessment of renal function and potassium in serum (28). The alternative is the spironolactone is eplerenone, which is administered at a dose of 50-100 mg/day. In case of failure to achieve optimal control of blood pressure (targeted blood pressure of less than $140 / 90 \mathrm{mmHg}$ ) and hygienic-dietary regime (restriction of salt intake: < $2.0 \mathrm{~g} /$ day $\mathrm{NaCl}$ ), potassium-sparing diuretics (amiloride or triamterene) or calcium channel blockers are administered (29).

\section{Pheochromocytoma}

Pheochromocytoma is a tumour made up of chromaffin cells of the adrenal marrow, which have the ability to produce and secrete catecholamines $(29,30)$. It is also referred to as the intra-adrenal paraganglioma (intraglandulary paraganglioma), unlike extra-adrenal sympathetic and parasympathetic paraganglioma (extra-glandular paraganglioma) $(29,30)$. The prevalence of pheochromocytoma in hypertensive patients is $0.1-0.5 \%$. Due to the paroxysmal release and increased catecholamine concentration in the serum, the clinical picture is characterized by the " $5 \mathrm{P}$ "s: paroxysmal hypertension, palpitation, increased perspiration, paleness and pulsating headache $(29,30)$. Paroxysmal hypertension may occur spontaneously or after physical exertion, after administration of certain medicines ( $\beta$-blockers, metoclopramide, glucagon, $\mathrm{ACTH}$ ) or as a result of an increase of the intra-abdominal pressure $(29,30)$.

Screening for pheochromocytoma should be performed in patients with resistant hypertension, a characteristic clinical picture (“5P”), hypertension after administration of $\beta$-blockers (paradoxical increase in arterial blood pressure after administration of $\beta$-blockers), hypertension while using antidepressants, as well as in patients with a jump in blood pressure during anaesthesia, surgery or angiographic procedures, patients with a family history of pheochromocytoma, and in patients with a history of genetic syndromes that are known to be associated with pheochromocytoma (multiple endocrine neoplasia type 2 (MEN 2), von Hippel Lindau syndrome (VHL syndrome) and neurofibromatosis type 1) $(29,30)$.

There are two screening tests available: the determination of the concentration of metanephrines and normetanephrines in the plasma and the 24-hour urine sample. Before performing the screening test, it is necessary to discontinue treatment with certain medicines (antidepressants, beta blockers, amphetamines, levodopa, phenoxybenzamine) and stimulants (alcohol, nicotine, caffeine). A concentration of metanephrines $>0.31 \mathrm{nmol} / \mathrm{l}$ and normetanephrines $>0.61 \mathrm{nmol} / \mathrm{l}$ in the plasma suggests an increased catecholamine secretion. A concentration of metanephrines $>0.7 \mu \mathrm{mol} / 24 \mathrm{~h}$ and normetanephrines $>1.7 \mu \mathrm{mol} / 24 \mathrm{~h}$ in the urine confirms the existence of pheochromocytoma $(29,30)$.

If one of the screening tests is positive, the following confirmatory testing is performed to verify the pheochromocytoma: clonidine suppression test and chromogranin concentration in plasma. The clonidine suppression test is performed by measuring the concentrations of catecholamines and metanephrines in the plasma before and 180 minutes after the administration of clonidine (clonidine per os, at a dose of $300 \mu \mathrm{g})$. The test is positive if the concentration of noradrenaline in the plasma is reduced by less than $50 \%$ or the normetanephrine concentration in the plasma by less than $40 \%$ (maintaining increased concentrations of noradrenaline and normetanephrine in the plasma after the administration of clonidine) (29, 30). A chromogranin plasma concentration $>270 \mathrm{ng} / \mathrm{ml}$ confirms the diagnosis of pheochromocytoma (29). Once the diagnosis of pheochromocytoma is confirmed, tests for the differential diagnosis of pheochromocytoma are conducted. Distinguishing unilateral from bilateral disease is achieved by a combination of techniques of display/visualization (computerized tomography (CT) or nuclear magnetic resonance (NMR) of adrenal glands, MIBG scintigraphy of adrenal glands $\left({ }^{123} \mathrm{I}\right.$ or ${ }^{131} \mathrm{I}$-metaiodbenzylguanidine) and PET scans of adrenal glands (fluorodopamine PET)). Pheochromocytoma is $3-6 \mathrm{~cm}$ in size and usually localized in the marrow of adrenal glands (80\%). If the pheochromocytoma is greater than $5.0 \mathrm{~cm}$, it is the malignant form of pheochromocytoma. MIBG scintigraphy is used to distinguish intra-adrenal (core of adrenal gland) from extra-glandular pheochromocytoma (paraganglioma) (29, 30). The radiological diagnosis of the abdomen, chest and neck should be performed to detect extra-adrenal pheochromocytoma. If MIBG scintigraphy is negative, and the suspected pheochromocytoma presence is big, a fluorodopamine PET scan should be conducted $(29,30)$.

Treatment is surgical and requires appropriate preoperative preparation. $\alpha$-Adrenoceptor antagonists (doxazosin, $\alpha_{1-}$ blocker) are applied 7-14 days prior to surgery to block effects of suddenly liberated catecholamines (pre- 
venting the development of hypertensive crisis and cardiac rhythm disorders) (29-31). Treatment begins with the administration of phenoxybenzamine at a dose of 10 $\mathrm{mg}$ twice a day, with a gradual increase in the dose of 10$20 \mathrm{mg} /$ day, every two to three days (total dose is approximately $1.0 \mathrm{mg} / \mathrm{kg} /$ day) $(30,31)$. In patients with tachycardia, beta blockers can be administered only after the alpha blockers. Atenolol is administered in a dose of $12.5-25 \mathrm{mg}$, twice a day, or metoprolol is administered in a dose of 25$50 \mathrm{mg}$, two to three times a day $(30,31)$.

\section{Cushing's Syndrome}

Cushing's syndrome is characterized by many symptoms and signs, which have been caused by increased concentrations of cortisol in the body tissue (purple stretch marks, plethoric appearance of the face, weakness of the proximal muscles, spontaneous bruising, unexplained osteoporosis, hypertension) (32-35). Depending on the aetiology, Cushing's syndrome can be distinguished into several types: one dependent of the adrenocorticotropic hormone (ACTH) (pituitary adenoma that secretes ACTH (Cushing's disease)) and the syndrome of ectopic secretion of ACTH (neuroendocrine tumours (bronchial carcinoids)), and Cushing's syndrome independent of ACTH (adenoma or cancer of the adrenal gland, adrenal hyperplasia) (32-35). The prevalence of Cushing's syndrome in patients with hypertension is $0.5-1.0 \%$. The mechanisms for hypertension in patients with Cushing's syndrome are multiple and include the following: mineralocorticosteroid activity of cortisol, activation of the renin-angiotensin-aldosterone system, increased reactivity to the vasoconstrictor effect (angiotensin 2, catecholamines, vasopressin), and reduced activity of the vasodilatory system (NO synthase, prostacyclin, kallikrein-kinin system) (32-35).

Testing for Cushing's syndrome is indicated in patients with the following factors: a typical clinical picture (hypertension and osteoporosis that are not in accordance with the age of patients) and resistant hypertension. Treatment for the iatrogenic Cushing's syndrome and medicines that affect the metabolism of dexamethasone and cortisol (phenytoin, phenobarbital, carbamazepine, rifampin, pioglitazone, diltiazem and cimetidine, fenofibrate, synthetic glucocorticoids) should be discontinued before the screening test (33-35).

For initial testing of patients with Cushing's syndrome, one of the following tests is recommended: the concentration of free cortisol in a 24-hour urine sample (UFC) (at least two measurements), the concentration of cortisol in saliva samples at night (11-12 pm) (two measurements), a night dexamethasone suppression test with $1.0 \mathrm{mg}$ of dexamethasone and a prolonged low-dose dexamethasone suppression test (dexamethasone suppression test (LDDST): $2.0 \mathrm{mg} /$ day, for $48 \mathrm{~h}$ ) (32-35). A concentration of free cortisol levels in the 24-hour urine sample $>250 \mu \mathrm{g} / 24 \mathrm{~h}$ points to Cushing's syndrome. The night dexamethasone test is performed by having the patient take $1.0 \mathrm{mg}$ of dexametha- sone per os, at night between $11 \mathrm{pm}$ and midnight, and then a blood sample is taken in the morning between 8 am and $9 \mathrm{am}$. A serum cortisol concentration greater than $1.8 \mu \mathrm{g} / \mathrm{dl}$ (> $50 \mathrm{nmol} / \mathrm{l}$ ) indicates a positive test (Cushing's syndrome). Cushing's syndrome is indicated by a concentration of cortisol in a saliva specimen (11-12 pm) greater than $145 \mathrm{ng} / \mathrm{dl}$ (> $4 \mathrm{nmol} / \mathrm{l}$ ) (32-34). Most endocrinologists recommended the low-dose dexamethasone suppression test (LDDST test: $0.5 \mathrm{mg} / 6 \mathrm{~h} / \mathrm{day}, 48 \mathrm{~h}$ ) for the screening test. The test is performed in such a way that the patient is taking dexamethasone in a dose of $0.5 \mathrm{mg}$ every 6 hours $(9 \mathrm{am}, 3 \mathrm{pm}, 9$ $\mathrm{pm}, 3 \mathrm{am})$. Serum cortisol concentration is determined at $9 \mathrm{am}$ (6 $\mathrm{h}$ after the last dose of dexamethasone). The test is positive if the concentration of serum cortisol levels is greater than $1.8 \mu \mathrm{g} / \mathrm{dl}$ (> $50 \mathrm{nmol} / \mathrm{l})(33-35)$.

In patients with one positive screening test, testing to confirm Cushing's syndrome is performed. These tests include the low-dose suppression test (LDDST: $2.0 \mathrm{mg} / \mathrm{day}$, $48 \mathrm{~h}$ ) in combination with a corticotrophin releasing factor (corticotrophin releasing hormone-CRH) (LDDST-CRH test). The test is performed in such a way that 2 hours after the last dose of dexamethasone, $\mathrm{CRH}$ is administered in a dose of $1.0 \mu \mathrm{g} / \mathrm{kg}$ IV, and cortisol levels are measured after 15 minutes. The test is positive if the concentration of serum cortisol levels, 15 minutes after CRH administration, is greater than $1.4 \mu \mathrm{g} / \mathrm{dl}(>38 \mathrm{nmol} / \mathrm{l})(33-35)$.

In patients who are diagnosed with Cushing's syndrome, tests are performed to diagnose subtypes of Cushing's syndrome (ACTH dependant Cushing's syndrome, ACTH independent Cushing's syndrome). Determining the ACTH concentration in the plasma is used for differential diagnosis of Cushing's syndrome. ACTH concentration in plasma of less than $5.0 \mathrm{pg} / \mathrm{ml}(<1.1 \mathrm{pmol} / \mathrm{l})$ points to the Cushing's syndrome that is ACTH independent (Cushing's syndrome dependent on the adrenal glands; non-pituitary form of Cushing's syndrome). Increased production and release of cortisol from the adenoma/carcinoma of the adrenal gland (increased concentration of serum cortisol) and a negative feedback mechanism reduce the formation and secretion of CRH from the hypothalamus and pituitary ACTH (reduced release of ACTH resulting in atrophy of the adrenal gland). If the ACTH concentration in the serum is greater than $20 \mathrm{pg} / \mathrm{ml}$ (>4.4 pmol/l), it implies a diagnosis of ACTH dependent Cushing's syndrome (pituitary tumour, ectopic tumour). A CRH stimulation test should be performed for the patients in whom the ACTH concentration in serum is between $5-20 \mathrm{pg} / \mathrm{ml}$ (1.1 to 4.4 $\mathrm{pmol} / \mathrm{l})$. The test is positive if the ACTH concentration in serum, after a CRH stimulation, is less than $30 \mathrm{pg} / \mathrm{ml}(<6.6$ $\mathrm{pmol} / \mathrm{l})(34,35)$.

After the confirmation of ACTH independent Cushing's syndrome (ACTH decreased concentration in serum), it is necessary to perform a CT or NMR of the adrenal glands (to determine the location of adrenal hyper secretion of cortisol). A CT or NMR of the endocranium (pituitary) and blood sampling from the pituitary gland vein (pituitary vein) are used for differential diagnosis of 
the pituitary from non-pituitary (ectopic) ACTH secretion. In clinical practice, venous blood to determine the $\mathrm{ACTH}$ concentration is taken from the petrosal sinus (IPS - inferior petrosal sinus) simultaneously from both sides. Blood from the anterior pituitary gland is directly flowing in these sinuses. For simultaneous evaluation of $\mathrm{ACTH}$ in systemic circulation, the venous blood sample is taken from the inferior vena cava (IVC). A significant ACTH gradient (IPS/IVC ratio $\geq 2.0$ ) indicates the secretion of ACTH from the pituitary gland adenoma (Cushing's disease). If the ACTH gradient is not important, $\mathrm{ACTH}$ is ectopically secreted (not from the pituitary gland) $(34,35)$. Analysing the results of endocrine diagnostic tests will provide accurate diagnosis of Cushing's syndrome.

Treatment is surgical and with medicines. Transsphenoidal pituitary surgery (removal of pituitary corticotropic adenoma) is indicated in patients who are diagnosed with Cushing's disease. If an adrenal gland tumour (adenoma/ carcinoma) is diagnosed, the unilateral laparoscopic adrenalectomy will be performed. Before surgical intervention, the administration of glucocorticoids is indicated for the prevention of sudden death due to secondary adrenal insufficiency (cortisol concentration increased, through a negative feedback mechanism, leads to atrophy of the contralateral adrenal gland) (34-36). In addition to surgical treatment, it is important to administer medicines that block the production of ACTH in the pituitary gland (pasireotide is a somatostatin analogue, to block the release of ACTH from the cells of pituitary adenomas), the creation of cortisol in the adrenal gland, and the effects of cortisol in the peripheral tissues (mifepristone is a receptor antagonist for glucocorticosteroids, and it has a higher affinity for the glucocorticosteroid receptor in relation to cortisol) (34-36).

\section{CONCLUSION}

Early diagnosis of secondary hypertension and a timely implementation of appropriate therapeutic procedures will ensure the optimum control of arterial blood pressure and prevent the development of cardiovascular morbidity and mortality in the patient population with hypertension.

\section{Acknowledgements:}

The authors would like to express their deepest gratitude to the Serbian Ministry of Science and Technological Development for their Grant No175014, which was used as one of the sources to financially support the study.

\section{REFERENCES}

1. Rimoldi SF, Scherrer U, Messerli FH. Secondary arterial hypertension: when, who, and how to screen? Eur Heart J 2014; 35(19):1245-54.
2. Kallistratos MS, Giannakopoulos A, German V, Manolis AJ. Diagnostic Modalities of the Most Common Forms of Secondary Hypertension. Hellenic J Cardiol 2010; 51:518-29.

3. Campese VM, Mitra N, Sandee D. Hypertension in renal parenchymal disease: Why is it so resistant to treatment? Kidney Int 2006; 69(6):967-73.

4. Campese VM. Pathophysiology of Resistant Hypertension in Chronic Kidney Disease. Semin Nephrol 2014; 34(5):571-6.

5. Sugiura T, Nakamori A, Wada A, Fukahara Y. Evaluation of tubulointerstitial injury by Doppler ultrasonography in glomerular disease. Clin Nephrol 2004; 61(2):119-26.

6. Sarafidis PA, Bakris GL. Resistant Hypertension. J Am Col Cardiol 2008; 52(22):1749-57.

7. Fagard RH. Resistant Hypertension. Heart 2012; 98(3):254-61.

8. Petrović D. Renovaskularna hipertenzija: etiopatogeneza, dijagnostika i lečenje. U: Akutno oštećenje bubrega u kliničkoj praksi. Petrović D. Ed. Fakultet medicinskih nauka Univerziteta u Kragujevcu, Interprint 2012: 353-63.

9. Baumgartner I, Lerman LO. Renovascular hypertension: screening and modern management. Eur Heart J 2011; 32(13):1590-8.

10. Petrović D. Renovaskularna hipertenzija: etiopatogeneza, dijagnostika i lečenje. U: Akutno oštećenje bubrega u kliničkoj praksi. Petrović D. Ed. Fakultet medicinskih nauka Univerziteta u Kragujevcu, Interprint 2012: 353-63.

11. Slovut DP, Onlin JW. Fibromuscular dysplasia. N Engl J Med 2004; 350(18):1862-71.

12. Sperati CJ, Aggarwal N, Arepally A, Atta MG. Fibromuscular dysplasia. Kidney Int 2009; 75(3):333-6.

13. Petrović D. Vojinović R, Lukić S, Novaković B, Mijailović M, Jagić N. Renovascular hypertension: diagnostic and therapy. Medicus 2005; 6(3):39-42.

14. Clarkson MR, Magee CN, Brenner BM. Renovascular Hypertension and Ischemic Nephropathy. In: The Kidney. Clarkson MR, Magee CN, Brenner BM. Eds. Philadelphia: Oxford University Press 2010: 468-86.

15. Radermacher J, Haller $\mathrm{H}$. The right diagnostic workup: investigating renal and renovascular disorders. J Hypertens 2003; 21 (Suppl 2):19-24.

16. Petrović D, Novaković B, Jagić N, Poskurica M, Stojimirović B. Klinički značaj kolor dopler ultrasonografije u dijagnostikovanju renovaskularne hipertenzije. U: Kardionefrologija 4. Radenković S. Ed. Niš: GIP PUNTA 2009: 188-93.

17. Granata A, Fiorini F, Andrulli S, Logias F, Galleni M, Romano G, Sicurezza E, Fiore CE. Doppler ultrasound and renal artery stenosis: An overview. J Ultrasound 2009; 12(4):133-43.

18. Gokhale S. Doppler Ultrasonography in Renovascular Hypertension. Ultrasound Clin 2010; 5(3):337-53.

19. Petrović D. Kontrastna nefropatija: etiopatogeneza, dijagnostika I lečenje. U: Akutno oštećenje bubrega u kliničkoj praksi. Petrović D. Ed. Fakultet medicinskih nauka Univerziteta u Kragujevcu, Interprint 2012: 373-88. 
20. Petrović D. Nefrogena sistemska fibroza: etiopatogeneza, dijagnostika i lečenje. U: Akutno oštećenje bubrega u kliničkoj praksi. Petrović D. Ed. Fakultet medicinskih nauka Univerziteta u Kragujevcu, Interprint 2012: 389-95.

21. Drieghe B, Madaric J, Sarno G, Manoharan G, Bartunek J, Heyndrickx GR, et al. Assessment of renal artery stenosis: side by-side comparison of angiography and duplex ultrasound with pressure gradient measurements. Eur Heart J 2008; 29(4):517-24.

22. Romero CA, Orias M, Weir M. Novel RAAS agonists and antagonists: clinical applications and controversies. Nat Rev Endocrinol 2015; 11(4):242-52.

23. Radermacher J, Chavan A, Bleck J, Vitzthum A, Stoess B, Gebel MJ, et al. Use of Doppler Ultrasonography to predict the outcome therapy for renal artery-stenosis. N Engl J Med 2001; 344(6):410-7.

24. Radermacher J. Echo-Doppler to predict the outcome for renal artery stenosis. J Nephrol 2002; 15(Suppl 6):69-76.

25. Wiecek A, Chudek J, Adamczak M. Indications for renal revascularisation - the landscape after the ASTRAL study. Nephrol Dial Transplant 2010; 25(8):2399-402.

26. Plouin PF, Bax L. Diagnosis and treatment of renal artery stenosis. Nat Rev Nephrol 2010; 6(3):151-9.

27. Mattsson C, Young WF. Primary aldosteronism: diagnostic and treatment strategies. Nat Clin Practice Nephrol 2006; 2(4):198-208.
28. Rossi GP. A comprehensive review of the clinical aspects of primary aldosteronism. Nat Rev Endocrinol 2011; 7(8):485-95.

29. Diederich S, Quinkler M, Morganti A, Bidlingmaier M. Endocirne Hypertension-Diagnosis and Treatment of Hormone-Induced Blood Pressure Disorders. Bremen: UNI-MED 2013: 12-87.

30. Pacak K, Eisenhofer G, Ahlman H, Bornstein SR, Gimenze-Roquelpo AP, Grossman AB, et al. Pheochromocytoma: recommendations for clinical practice from the First International Symposium. Nat Clin Pract Endocrinol Metabolism 2007; 3(2):92-102.

31. Pacak K. Preoperative Management of the Pheochromocytoma Patient. J Clin Endocrinol Metab 2007; 92(11):4069-79.

32. Cicala MV, Mantero F. Hypertension in Cushings Syndrome: from Pathogenesis to Treatment. Neuroendocrinology 2010; 92(Suppl 1):44-9.

33. Nieman LK, Biller BMK, Findling JW, Price JN, Savage MO, Stewart PM, Montori VM. The Diagnosis of Cushings Syndrome. An Endocrine Society Clinical Practice Guideline. J Clin Endocrinol Metab 2008; 93(5):1256-40.

34. Raff H, Findling JW. A Physilogic Approach to Diagnosis of the Cushing Syndrome. Ann Intern Med 2003; 138(12):980-91.

35. Raff H, Carroll T. Cushing,s syndrome: from physiological principles to diagnosis and clinical care. J Physiol 2015; 593(3):494-506.

36. Sica DA. Endocrine Causes of Secondary Hypertension. J Clin Hypertens 2008; 10(7):534-40. 